Check for updates

Cite this: RSC Adv., 2021, 11, 39118

Received 16th September 2021 Accepted 29th November 2021

DOI: $10.1039 / \mathrm{d} 1 \mathrm{ra06936e}$

rsc.li/rsc-advances

\section{Fabrication of polyoxometalate-modified palladium-nickel/reduced graphene oxide alloy catalysts for enhanced oxygen reduction reaction activity}

\author{
Fereshteh Dehghani Sanij, ${ }^{a}$ Prabhuraj Balakrishnan, ${ }^{a}$ Huaneng Su, ${ }^{a}$ \\ Lindiwe Khotseng (D) ${ }^{\mathrm{b}}$ and Qian Xu (iD) *a
}

Designing advanced nanocatalysts for effectively catalyzing the oxygen reduction reaction (ORR) is of great importance for practical applications of direct methanol fuel cells (DMFCs). In this work, the reduced graphene oxide ( $\mathrm{rGO}$ )-supported palladium-nickel ( $\mathrm{Pd}-\mathrm{Ni} / \mathrm{rGO})$ alloy modified by the novel polyoxometalate (POM) with Keggin structure ( $\mathrm{Pd}-\mathrm{Ni} / \mathrm{rGO}-\mathrm{POM})$ is efficiently fabricated via an impregnation technique. The physical characterizations such as X-ray diffraction (XRD), Fourier transform infrared spectroscopy (FT-IR), Raman spectroscopy, inductively coupled plasma optical emission spectroscopy (ICP-OES), field emission scanning electron microscopy coupled with energy dispersive $\mathrm{X}$ ray spectroscopy (FESEM-EDX), and transmission electron microscopy (TEM) are utilized to confirm the structure, morphology, and chemical composition of the fabricated samples. The XRD results verify the formation of the POM-modified $\mathrm{Pd}_{8} \mathrm{Ni}_{2} / \mathrm{rGO}$ alloy electro-catalyst with the face-centered-cubic (fcc) structure and average crystallite size of $5.54 \mathrm{~nm}$. The electro-catalytic activities of the nanocatalysts towards ORR in alkaline conditions are evaluated by cyclic voltammetry (CV), rotating disk electrode (RDE), and chronoamperometry (CA) analyses. The synthesized $\mathrm{Pd}_{8} \mathrm{Ni}_{2} / \mathrm{rGO}-\mathrm{POM}$ nanomaterial shows remarkably greater ORR catalytic activity and better methanol resistance compared with the $\mathrm{Pd}_{8} \mathrm{Ni}_{2} / \mathrm{rGO}$ and $\mathrm{Pd} / \mathrm{rGO}$ electro-catalysts. The promoted ORR activity of the $\mathrm{Pd}_{8} \mathrm{Ni}_{2} / \mathrm{rGO}-\mathrm{POM}$ sample is attributed to the alloying of $\mathrm{Pd}$ and $\mathrm{Ni}$ components, the uniform scattering of $\mathrm{Pd}-\mathrm{Ni}$ nanoparticles on $\mathrm{rGO}$, and the alloyed catalyst being modified with POM. Moreover, these findings demonstrate that the resultant $\mathrm{Pd}_{8} \mathrm{Ni}_{2} / \mathrm{rGO}-\mathrm{POM}$ material is attractive as a suitable and cost-effective cathodic catalyst for DMFCs, in which the decorated POMs play a vital role for the enhancement in the catalytic abilities of the nanocatalyst.

\section{Introduction}

Direct methanol fuel cells (DMFCs) have aroused great interest for energy conversion and storage in recent years due to the marked benefits, including high efficiency, simple construction, ease of charging, and non-polluting nature..$^{1-3}$ Nonetheless, the practical development of DMFC technologies is hampered by some challenges such as the exorbitant price of platinum (Pt) electro-catalysts, slow kinetics of the oxygen reduction reaction (ORR), and inevitable crossover of methanol through the membrane. ${ }^{4-6}$ Hence, developing cost-effective, efficient, and methanol-resistant catalysts for the ORR is of tremendous significance.

Institute for Energy Research, Jiangsu University, Zhenjiang 212013, China. E-mail: xuqian@ujs.edu.cn

${ }^{b}$ Department of Chemistry, University of the Western Cape, Cape Town 7535, South Africa
In this context, palladium (Pd)-containing electro-catalysts, as attractive potential substitutes, have been actively explored for oxygen reduction in DMFC systems since Pd nanomaterials possess comparatively higher ORR activity compared with that of Pt electro-catalyst, but they are considerably cheaper than platinum. ${ }^{7,8}$ Besides, to promote the ORR performance of nanoparticulated Pd catalysts, diverse alloyed materials, alternative substrates, and modified nanocatalysts have been developed. ${ }^{9-12}$ With the continuing growth of nanotechnologies, various investigations have reported that Pd-based alloy materials are becoming appealing nanocatalysts. A variety of alloyed materials like PdCu, ${ }^{13} \mathrm{PdFe},{ }^{8,14,15} \mathrm{PdAg},{ }^{16} \mathrm{PdCo},{ }^{17,18}$ and $\mathrm{PdAu}^{19}$ have been investigated on account of their greater catalytic activity and cost-effectiveness. Pd-containing bimetallic alloyed catalysts, especially $\mathrm{Pd}-\mathrm{Ni}$ alloys, indicate better electrocatalytic capabilities compared with monometallic systems. ${ }^{20,21}$

On the other hand, to enhance the electro-catalytic ability and support the nanocatalysts, different kinds of carbon substrates such as carbon black, ${ }^{10}$ carbon nanotubes (CNTs), ${ }^{22,23}$ 
and graphite ${ }^{24}$ have been employed when utilizing Pd or Pd alloy nanoparticles for the oxygen reduction. Among them, reduced graphene oxide (rGO), as a suitable electro-catalyst substrate, has been widely exploited owing to high chemical stability along with striking electron transport properties..$^{25-27}$

Recently, polyoxometalates (POMs) have also been integrated with nanocatalysts to increase their ORR catalytic activity. POMs, which have triggered substantial attention to be employed in electro-catalysis, ${ }^{28}$ energy conversion and storage systems, ${ }^{29,30}$ medicine, ${ }^{31,32}$ and material science, ${ }^{33}$ are the nanoscale high-valent transition metal-oxygen anionic cluster compounds with distinctive molecular structures and fascinating physicochemical properties. ${ }^{34,35}$ POMs have the ability to function as proton acceptors and conductors, which makes the ORR process easier. ${ }^{36}$ In addition, POMs reveal prominent capabilities for reducing hydrogen peroxide to water, which is the rate-controlling stage in oxygen reduction catalysis. ${ }^{37,38}$ In particular, the Keggin-type POMs can be readily adsorbed on Pd-based catalyst surface, and they are able to efficiently enhance the oxygen reduction activity by facilitating the charge transfer during the ORR process. Such POM modification of the Pd-based nanocatalysts would offer benefits like improved stability of the electro-catalysts and remarkable activity for ORR. ${ }^{39}$

The nanocatalysts created by depositing POMs on carbonous materials are more prospective than pure POMs since this enhances the low conductivity of POMs and promotes their catalytic performance. Among the carbon materials, graphenebased nanomaterials have been recognized as the most desirable carriers for POMs because they have rich channels and pores for the diffusion of oxygen in the oxygen reduction electro-catalysis procedures. For instance, Liu et al. synthesized innovative ternary Ag NPs@POM/rGO hybrids by a green and simple method. Interestingly, owing to the synergistic effects of Ag nanoparticles, rGO, and POM, the synthesized ternary nanohybrids revealed exceptional electro-catalytic performances towards oxygen reduction through a direct $4 \mathrm{e}^{-}$procedure. ${ }^{40}$ In another study, Li et al. reported the preparation of Pd/ $\mathrm{POM} / \mathrm{rGO}$ nanocomposite with the help of POM for ORR. Their results confirmed the consistent dispersion of the nanosized Pd particles on the rGO surfaces. Porous nanostructures and excellent conductivity, which can be caused by the interactions between rGO and POMs, seem to be favorable for improving the permeation of reactants. The fabricated nanomaterial demonstrated superior electro-catalytic ability and better methanol resistance as compared to other studied samples. ${ }^{39}$ Inspired by the previous studies, the fabrication of novel POM-modified Pd alloyed nanoparticles/rGO appears highly promising.

Despite the benefits of applying decorated POMs on the Pt electro-catalysts, the impacts of POM modification of Pd-based alloy nanomaterials on catalysis of oxygen reduction reaction have been described rarely, presumably because the Pt and Ptbased catalysts are currently in their real implementation in fuel cell technologies, while the Pd and POMs are still in their ongoing investigation phase. Thus, the design of POM-modified $\mathrm{Pd}-\mathrm{Ni} / \mathrm{rGO}$ material as an efficient nanocatalyst for oxygen reduction in DMFC systems is a challenging task. In the present study, POM-modified $\mathrm{Pd}_{8} \mathrm{Ni}_{2} / \mathrm{rGO}$ (henceforth designated as $\mathrm{Pd}_{8} \mathrm{Ni}_{2} / \mathrm{rGO}-\mathrm{POM}$ ) was fabricated via the facile impregnation method, in which well-dispersed Pd-Ni nanoparticles were first prepared and anchored on the rGO surface, and then POM was decorated on the $\mathrm{Pd}_{8} \mathrm{Ni}_{2} / \mathrm{rGO}$ sample. These nanocatalysts were structurally characterized using various physicochemical techniques. Furthermore, their electro-catalytic behaviors towards ORR were compared with $\mathrm{Pd}_{8} \mathrm{Ni}_{2} / \mathrm{rGO}$ and $\mathrm{Pd} / \mathrm{rGO}$ to assess the influences of $\mathrm{rGO}$ and POM over the prepared $\mathrm{Pd}_{8} \mathrm{Ni}_{2} / \mathrm{rGO}-\mathrm{POM}$ nanocatalysts. The electro-chemical results revealed that $\mathrm{Pd}_{8} \mathrm{Ni}_{2} / \mathrm{rGO}-\mathrm{POM}$ has the highest activity and stability for oxygen reduction comparing to the other two catalysts. Hence, it is worthwhile to employ such an outstanding $\mathrm{Pd}_{8} \mathrm{Ni}_{2} / \mathrm{rGO}-\mathrm{POM}$ nanomaterial as the cathode electro-catalyst for DMFCs.

\section{Experimental}

\subsection{Materials}

Graphite powder, Nafion solution (5 wt\%), disodium hydrogen phosphate $\left(\mathrm{Na}_{2} \mathrm{HPO}_{4}\right)$, potassium permanganate $\left(\mathrm{KMnO}_{4}\right)$, sodium tungstate dihydrate $\left(\mathrm{Na}_{2} \mathrm{WO}_{4} \cdot 2 \mathrm{H}_{2} \mathrm{O}\right)$, and sodium molybdate dihydrate $\left(\mathrm{Na}_{2} \mathrm{MoO}_{4} \cdot 2 \mathrm{H}_{2} \mathrm{O}\right)$ were supplied from Sigma-Aldrich. Methanol $(\mathrm{MeOH})$, hydrochloric acid $(\mathrm{HCl})$, nickel(II) chloride hexahydrate $\left(\mathrm{NiCl}_{2} \cdot 6 \mathrm{H}_{2} \mathrm{O}\right)$, sulfuric acid $\left(\mathrm{H}_{2} \mathrm{SO}_{4}\right)$, palladium(II) nitrate dihydrate $\left(\mathrm{Pd}\left[\mathrm{NO}_{3}\right]_{2} \cdot 2 \mathrm{H}_{2} \mathrm{O}\right)$, ethylene glycol (EG), nitric acid $\left(\mathrm{HNO}_{3}\right)$, sodium hydroxide $(\mathrm{NaOH})$, diethyl ether $\left(\mathrm{Et}_{2} \mathrm{O}\right)$, isopropyl alcohol (IPA), hydrogen peroxide $\left(\mathrm{H}_{2} \mathrm{O}_{2}\right)$, and sodium nitrate $\left(\mathrm{NaNO}_{3}\right)$ were purchased from Merck. Commercial Pt/C product (20 wt\%, from ETECK) and other chemical materials involved were utilized as received. All chemicals in this investigation were directly used with no more pretreatments. Deionized (DI) water was employed to dilute and dissolve chemical reagents during the experiments.

\subsection{Preparation of $\mathbf{P d}-\mathrm{Ni} / \mathrm{rGO}$ electro-catalysts}

The modified Hummers' method ${ }^{\mathbf{4 1 , 4 2}}$ was utilized to produce GO from graphite powder. An impregnation technique was used for the synthesis of the binary Pd-Ni alloy materials with $10 \mathrm{wt} \%$ metal content, as detailed in our earlier work. ${ }^{21}$ In short, the GO was initially suspended in a mixture of IPA/ $\mathrm{H}_{2} \mathrm{O}\left(10 \mathrm{ml}, V_{\text {IPA }} /\right.$ $\left.V_{\mathrm{H} 2 \mathrm{O}}=1: 1\right)$ and exfoliated by ultrasonic processing for half an hour to generate a uniform dispersion. Based on the atomic proportions of samples, certain amounts of $\mathrm{Pd}(0.033 \mathrm{mmol}, \mathrm{Pd}$ $\left.\left[\mathrm{NO}_{3}\right]_{2} \cdot 2 \mathrm{H}_{2} \mathrm{O}\right)$ and $\mathrm{Ni}\left(0.019 \mathrm{mmol}, \mathrm{NiCl}_{2} \cdot 6 \mathrm{H}_{2} \mathrm{O}\right)$ precursors were then added into the support solution under continuous stirring for 15 min till the suspension was well blended. To complete the reduction of metallic ions, after adjusting the $\mathrm{pH}$ value to $10-12$ by means of $1.0 \mathrm{M} \mathrm{NaOH}$ and then subsequently adding EG $(60 \mathrm{ml})$ as a reducing factor, the mentioned mixture was stirred at $120{ }^{\circ} \mathrm{C}$ under the blow of argon (Ar) with continuous reflux for $16 \mathrm{~h}$. At this step, the bimetallic Pd-Ni alloyed nanoparticles supported on rGO were constructed because of the simultaneous reduction of metallic ions and GO. The achieved solution was naturally cooled down to room temperature (RT), and the solid powders were separated using centrifugation and rinsed three times with DI water for 
eliminating any residual precursors along with maintaining the $\mathrm{pH}$ about 7. After then, the final product was kept in the oven at $70{ }^{\circ} \mathrm{C}$ for overnight drying and denoted by $\mathrm{Pd}_{8} \mathrm{Ni}_{2} / \mathrm{rGO}$. For comparative investigation in oxygen reduction, $\mathrm{Pd} / \mathrm{rGO}$ catalyst was synthesized adopting a similar approach through mixing a dispersion of GO with appropriate amounts of Pd precursor $\left(0.041 \mathrm{mmol}, \mathrm{Pd}\left[\mathrm{NO}_{3}\right]_{2} \cdot 2 \mathrm{H}_{2} \mathrm{O}\right)$. All the other preparation steps were maintained the same as those needed for fabricating binary alloyed $\mathrm{Pd}-\mathrm{Ni} / \mathrm{rGO}$ catalyst.

\subsection{Preparation of Pd-Ni/rGO-POM electro-catalyst}

The $\mathrm{H}_{3}\left[\mathrm{PMo}_{4} \mathrm{~W}_{8} \mathrm{O}_{40}\right]$ was prepared through the described process by Huixiong et al. ${ }^{\mathbf{4 3}}$ The $\mathrm{Pd}-\mathrm{Ni} / \mathrm{rGO}-\mathrm{POM}$ electro-catalyst was fabricated as follows: $0.02 \mathrm{~g}$ of $\mathrm{Pd}-\mathrm{Ni} / \mathrm{rGO}$ nanocatalyst was immersed in $2.58 \times 10^{-3} \mathrm{M}$ POM solution.

Afterwards, this mixture ( $\mathrm{pH} \sim 6.5$ ) was kept stirring for $12 \mathrm{~h}$. Ultimately, after the resulting product was filtered, rinsed, and dried for $24 \mathrm{~h}$ in a vacuum oven at $60{ }^{\circ} \mathrm{C}$, the Pd-Ni/rGO-POM sample was acquired. Scheme 1 demonstrates the synthetic process of the $\mathrm{Pd}_{8} \mathrm{Ni}_{2} / \mathrm{rGO}-\mathrm{POM}$ electro-catalyst.

\subsection{Physical characterization}

The crystal nanostructures of fabricated materials were achieved with recording X-ray diffraction (XRD) scans by filtered Co $\mathrm{K} \alpha$ radiation on a Phillips X'Pert MPD diffractometer. The Fourier transform infrared (FTIR) measurements were carried out on a Nicolet AVATAR 370 spectrometer within the spectral range of 600 and $4000 \mathrm{~cm}^{-1}$. The Raman spectra were achieved using an Almega Thermo Nicolet dispersive Raman spectrometer with a $532 \mathrm{~nm}$ laser excitation source. The inductively coupled plasma optical emission spectroscopy (ICP-OES) was performed on a PerkinElmer Optima 8000 instrument. The field emission scanning electron microscopy (FESEM) and energydispersive X-ray spectroscopy (EDX) together with the corresponding elemental mapping were conducted on a TESCAN Mira 3-XMU. The transmission electron microscopy (TEM) images were collected on a Phillips model CM200 microscope.

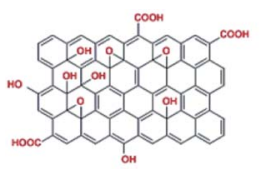

Graphene Oxide (GO)

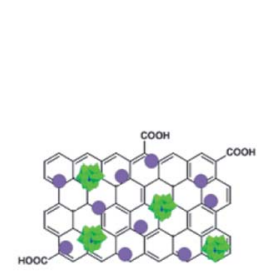

$\mathrm{Pd}-\mathrm{Ni} / \mathrm{rGO}-\mathrm{POM}$

- $\mathrm{Pd}^{+2}-\mathrm{Ni}^{+2}$ Pd-Ni alloy

POM
Scheme 1 Schematic illustration of the synthetic process for the $\mathrm{Pd}_{8} \mathrm{Ni}_{2} / \mathrm{rGO}$-POM electro-catalyst.

\subsection{Electro-chemical characterization}

All the electro-chemical ORR studies of prepared nanocatalysts were performed on a three-electrode based system in $0.1 \mathrm{M} \mathrm{KOH}$ or $0.1 \mathrm{M} \mathrm{KOH} / 1 \mathrm{M} \mathrm{MeOH}$ solutions saturated with $\mathrm{O}_{2}$ as electrolyte. In this research, the catalytic tests were conducted at $25{ }^{\circ} \mathrm{C}$, and a fabricated nanomaterial loaded glassy carbon (GC, area of $0.031415 \mathrm{~cm}^{2}$ ) was served as a working electrode. An Ag/ $\mathrm{AgCl}$ (saturated with $\mathrm{KCl}$ ) and a $1 \mathrm{~cm}^{2}$ Pt plate were utilized as reference and auxiliary electrodes, respectively.

The suspension of as-obtained sample powders $(1 \mathrm{mg})$ in a mixed solvent ( $1 \mathrm{~mL}$, IPA and $\mathrm{H}_{2} \mathrm{O}=2: 1$ ) and Nafion ionomer (1 $\mathrm{mL}, 0.18 \mathrm{mg} \mathrm{mL} \mathrm{m}^{-1}$ ) was formed by a $20 \mathrm{~min}$ sonication. Before coating the electro-catalyst samples on the surface of the electrode for electro-chemical measurements, the GC electrode was polished successively by alumina slurries and cleaned ultrasonically in DI water. The specified amount of respective electro-catalyst suspension was then coated evenly on the working area of cleaned GC electrodes. Eventually, after air drying, the metal loading of studied nanomaterial on the active surface of each electrode was set to $0.1 \mathrm{mg} \mathrm{cm}^{-2}$.

Cyclic voltammetry (CV) curves were recorded in the potential range of -1.2 to $0.2 \mathrm{~V} v s$. $\mathrm{Ag} / \mathrm{AgCl}$ at the scanning rate of $50 \mathrm{mV} \mathrm{s}^{-1}$. Linear sweep voltammetry (LSV) experiments were conducted on rotating disk electrodes (RDE) with various rotating per minute (rpm) velocities (400 to $2000 \mathrm{rpm}$ ) at the scan rate of $5 \mathrm{mV} \mathrm{s}^{-1}$. Chronoamperometry (CA) measurements were accomplished at a fixed potential of $-0.4 \mathrm{~V} v s$. Ag/AgCl.

\section{Result and discussion}

\subsection{Physical characterization of electro-catalysts}

The structures of the synthesized materials were examined using XRD analyses. As indicated in the XRD patterns of the studied nanocatalysts (Fig. 1a), the first peak at around $28^{\circ}$ is assigned to the (002) plane of rGO support. ${ }^{44}$ The Pd/rGO catalyst presented the typical peaks of a crystalline face-centeredcubic (fcc) Pd, which are related to the (111), (200), and (220) planes (JCPDS-46-1043). For $\mathrm{Pd}_{8} \mathrm{Ni}_{2} / \mathrm{rGO}$ and $\mathrm{Pd}_{8} \mathrm{Ni}_{2} / \mathrm{rGO}-\mathrm{POM}$, the $\mathrm{Pd}$ diffraction peaks showed a slight shifting relative to $\mathrm{Pd} / \mathrm{rGO}$, demonstrating that alloying of Ni with Pd was conducted. ${ }^{45}$ Notably, no clear characteristic peaks of individual $\mathrm{Ni}$ elements can be observed, further signifying that the $\mathrm{Pd}-\mathrm{Ni}$ alloy systems are successfully generated. ${ }^{46}$ Besides, the $\mathrm{Pd}_{8} \mathrm{Ni}_{2} /$ rGO-POM nanomaterial does not exhibit any peaks of POM in the XRD patterns, implying that the POM structures are present in the dispersed form instead of the crystalline form. ${ }^{47,48}$ The average crystallite sizes of the $\mathrm{Pd} / \mathrm{rGO}, \mathrm{Pd}_{8} \mathrm{Ni}_{2} / \mathrm{rGO}$, and $\mathrm{Pd}_{8} \mathrm{Ni}_{2} /$ rGO-POM catalysts were evaluated by Scherrer's equation ${ }^{\mathbf{9}}$ utilizing $\operatorname{Pd}(111)$ reflection, and the obtained results are depicted in Table 1 . As shown in Table 1, the incorporation of $\mathrm{Ni}$ into Pd can inhibit the growth of Pd-Ni nanocrystals, resulting in smaller crystallite sizes. ${ }^{\mathbf{5 0 , 5 1}}$ The calculated average crystallite sizes of the $\mathrm{Pd}_{8} \mathrm{Ni}_{2} / \mathrm{rGO}$ and $\mathrm{Pd}_{8} \mathrm{Ni}_{2} / \mathrm{rGO}$-POM electro-catalysts are both $5.54 \mathrm{~nm}$, which will be confirmed by the TEM results later. 

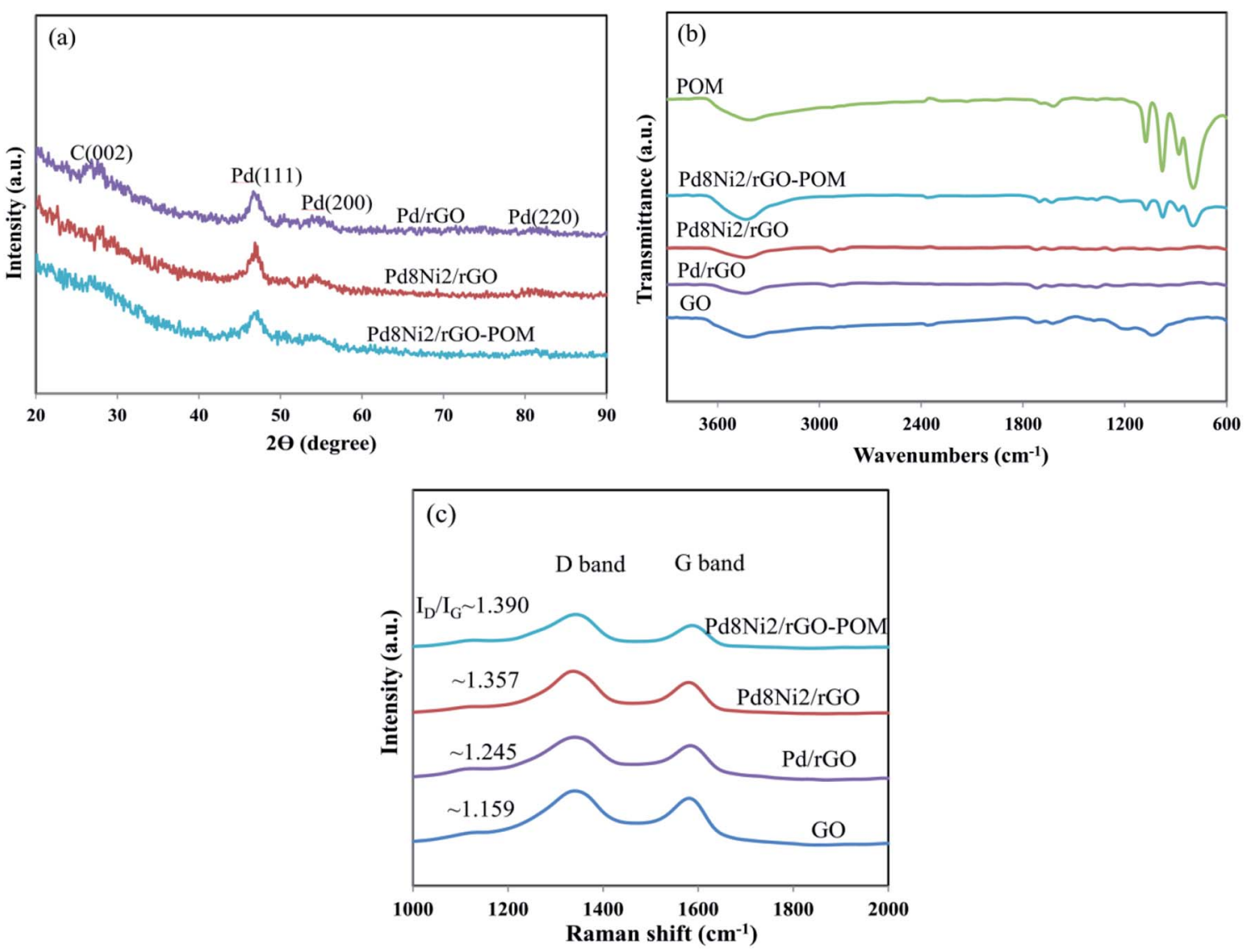

Fig. 1 XRD patterns (a), FTIR spectra (b), and Raman spectra (c) for different nanomaterials.

The FT-IR spectra of synthesized nanostructures are indicated in Fig. 1b. As displayed in Fig. 1b, the FT-IR spectrum of GO presents the characteristic peaks at $3407,1711,1624,1351$, and $1041 \mathrm{~cm}^{-1}$, which were associated with the $\mathrm{O}-\mathrm{H}, \mathrm{C}=\mathrm{O}, \mathrm{C}=$ $\mathrm{C}, \mathrm{C}-\mathrm{OH}$, and $\mathrm{C}-\mathrm{O}$ stretching vibrations, respectively. ${ }^{52,53}$ In the case of prepared rGO-supported catalysts, the decreased intensities of characteristic peaks originating from oxygen functionalities signify the efficient reduction of GO to $\mathrm{rGO}^{54}$ The absorption bands at $1072 \mathrm{~cm}^{-1}\left(\nu_{\text {as }}(\mathrm{P}-\mathrm{O})\right), 977 \mathrm{~cm}^{-1}\left(\nu_{\text {as }}(-\right.$ metal $=\mathrm{O})), 879 \mathrm{~cm}^{-1}\left(\nu_{\text {as }}(\right.$ metal-O-metal $\left.)\right)$, and $786 \mathrm{~cm}^{-1}$ $\left(\nu_{\text {as }}(\right.$ metal-O-metal $\left.)\right)$ belonging to the main characteristic peaks of POM, were depicted in the FT-IR spectral scan of POM. ${ }^{43}$ These observations approve that the POM has the Keggin structure. The FT-IR spectrum of $\mathrm{Pd}_{8} \mathrm{Ni}_{2} / \mathrm{rGO}-\mathrm{POM}$ exhibited that the POM structure has remained in the catalyst and verified the existence of POM in the prepared nanomaterial (Fig. 1b).

Fig. 1c illustrates the Raman spectra of $\mathrm{GO}, \mathrm{Pd} / \mathrm{rGO}, \mathrm{Pd}_{8} \mathrm{Ni}_{2} /$ rGO, and $\mathrm{Pd}_{8} \mathrm{Ni}_{2} / \mathrm{rGO}-\mathrm{POM}$ materials, in which the D-band $\left(\sim 1343 \mathrm{~cm}^{-1}\right)$ is associated with the intervention of the $\mathrm{sp}^{2}$ hybridized carbon atoms and the G-band $\left(\sim 1583 \mathrm{~cm}^{-1}\right)$ is assigned to the $\mathrm{sp}^{2}$ hybridized carbon atoms within the hexagonal graphite networks. The peak intensity ratio of these two bands, $I_{\mathrm{D}} / I_{\mathrm{G}}$, is generally utilized to assess the size of $\mathrm{sp}^{2}$ domains and disorder degrees in graphite materials. ${ }^{55,56}$ The differences in values of $I_{\mathrm{D}} / I_{\mathrm{G}}$ can be due to the incremented defects in graphene nanosheets, which originate from the electronic relations between carbon atoms and metallic nanoparticles (Fig. 1c). In comparison to $\mathrm{GO}$, the $I_{\mathrm{D}} / I_{\mathrm{G}}$ value

Table 1 Physical characterization results of the $\mathrm{Pd} / \mathrm{rGO}, \mathrm{Pd}_{8} \mathrm{Ni}_{2} / \mathrm{rGO}$, and $\mathrm{Pd}_{8} \mathrm{Ni}_{2} / \mathrm{rGO}-\mathrm{POM}$ electro-catalysts

\begin{tabular}{|c|c|c|c|c|c|c|c|}
\hline \multirow{2}{*}{ Electro-catalyst } & \multicolumn{5}{|c|}{ Composition } & \multirow{2}{*}{$\begin{array}{l}\text { Crystallite size } \\
(\mathrm{nm}), \text { XRD }\end{array}$} & \multirow{2}{*}{$\begin{array}{l}\text { Particle size } \\
\text { (nm), TEM }\end{array}$} \\
\hline & \multicolumn{4}{|l|}{ ICP (wt\%) } & $\frac{\mathrm{EDX}}{\mathrm{Pd} / \mathrm{Ni}}$ & & \\
\hline $\mathrm{Pd} / \mathrm{rGO}$ & 9.85 & - & - & - & - & 7.66 & 7.57 \\
\hline $\mathrm{Pd}_{8} \mathrm{Ni}_{2} / \mathrm{rGO}$ & 7.59 & 2.25 & - & - & 4.36 & 5.54 & 5.38 \\
\hline
\end{tabular}



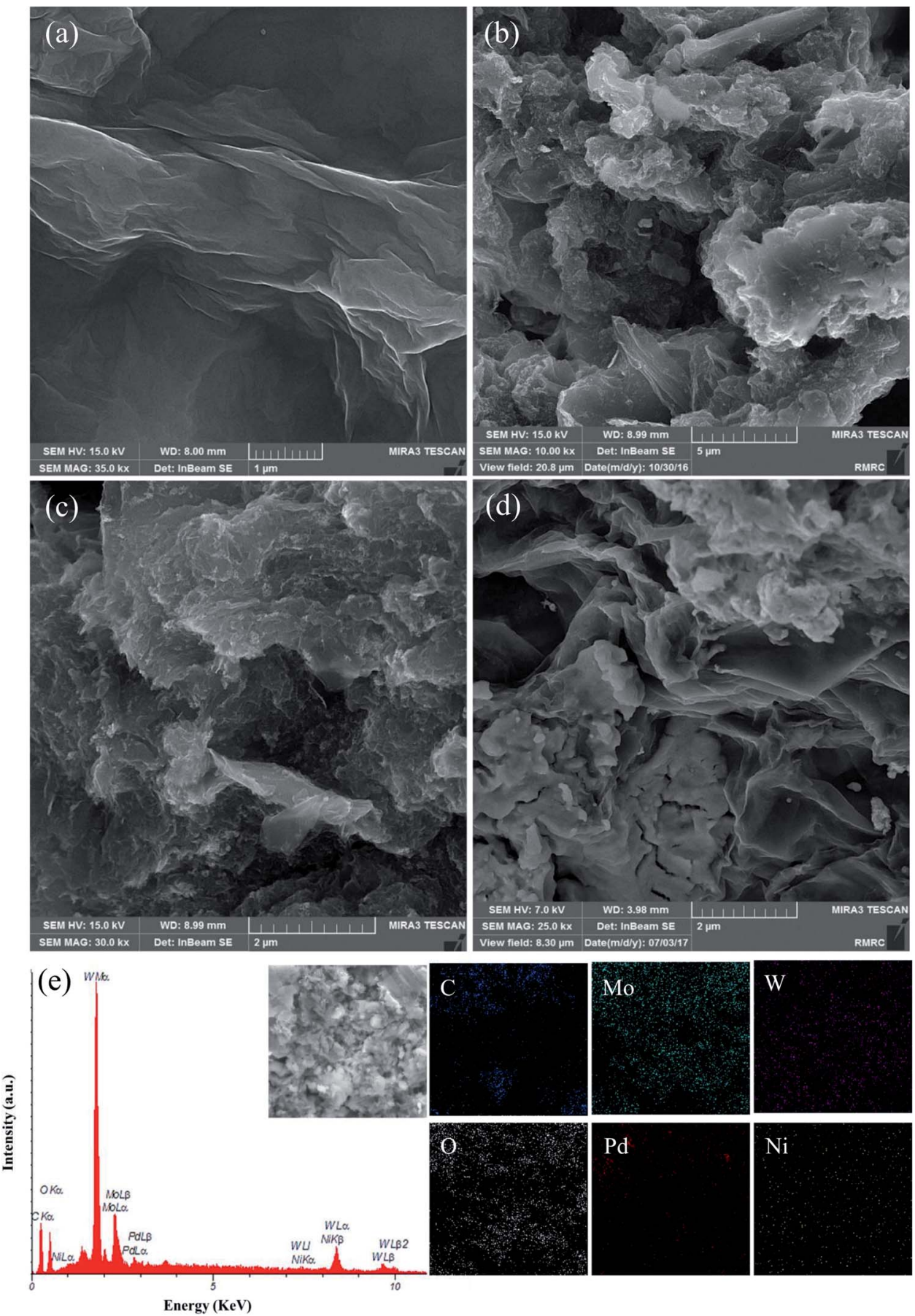

Fig. 2 FESEM images of the $\mathrm{GO}$ (a) $\mathrm{Pd} / \mathrm{rGO}$ (b), $\mathrm{Pd}_{8} \mathrm{Ni}_{2} / \mathrm{rGO}$ (c), $\mathrm{Pd}_{8} \mathrm{Ni}_{2} / \mathrm{rGO}-\mathrm{POM}$ (d), EDX spectrum and elemental mappings of C, Mo, W, O, Pd, and $\mathrm{Ni}(\mathrm{e})$ for the $\mathrm{Pd}_{8} \mathrm{Ni}_{2} / \mathrm{rGO}-\mathrm{POM}$.

incremented for all as-prepared nanomaterials, which demonstrates that the GO nanosheets have been efficiently reduced to form graphene. ${ }^{57}$

The morphologies of GO, Pd/rGO, $\mathrm{Pd}_{8} \mathrm{Ni}_{2} / \mathrm{rGO}$, and $\mathrm{Pd}_{8} \mathrm{Ni}_{2} /$ rGO-POM samples were examined using FESEM (Fig. 2). FESEM image of GO shows thin layered structures with smooth surfaces and slightly crumpled edge planes (Fig. 2a). As seen in Fig. 2b and $\mathrm{c}$, the nanosized $\mathrm{Pd}$ and $\mathrm{Pd}_{8} \mathrm{Ni}_{2}$ particles were homogeneously dispersed onto the rGO surface. After the decoration of
POM on the $\mathrm{Pd}_{8} \mathrm{Ni}_{2} / \mathrm{rGO}$ catalyst, the surfaces of the rGO substrate were also covered by POM particles (Fig. 2d). The elemental mapping images of $\mathrm{Pd}_{8} \mathrm{Ni}_{2} / \mathrm{rGO}-\mathrm{POM}$ for $\mathrm{C}, \mathrm{Mo}, \mathrm{W}, \mathrm{O}$, $\mathrm{Pd}$, and Ni elements are shown in Fig. 2e. The simultaneous existence of constituent elements in $\mathrm{Pd}_{8} \mathrm{Ni}_{2} / \mathrm{rGO}-\mathrm{POM}$ presents the effective preparation of this catalyst. Moreover, the elemental mappings confirm the even dispersity of all the components in the $\mathrm{Pd}_{8} \mathrm{Ni}_{2} / \mathrm{rGO}-\mathrm{POM}$ material. 

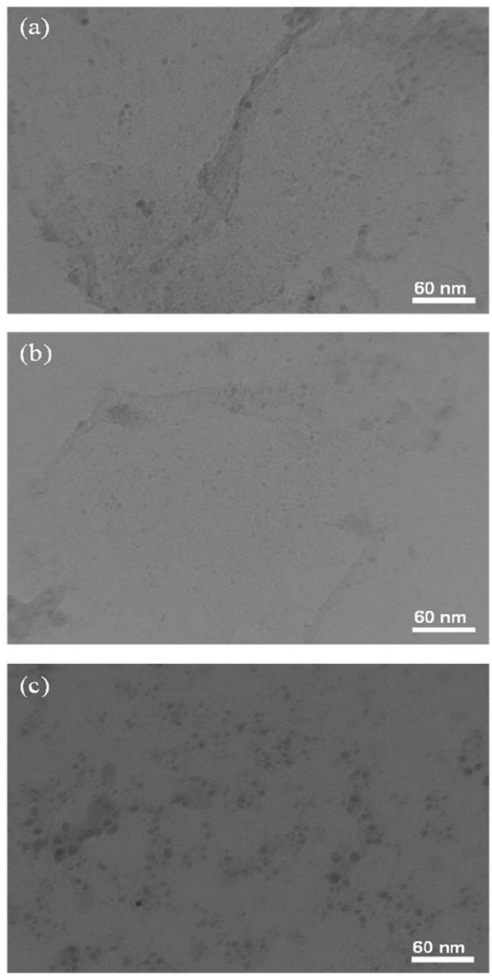

Fig. 3 TEM images of the $\mathrm{Pd} / \mathrm{rGO}$ (a), $\mathrm{Pd}_{8} \mathrm{Ni}_{2} / \mathrm{rGO}$ (b), and $\mathrm{Pd}_{8} \mathrm{Ni}_{2} /$ rGO-POM (c)

EDX and ICP-OES measurements were carried out to analyze the composition of the synthesized nanomaterials (Table 1). The characteristic peaks of $\mathrm{C}, \mathrm{O}, \mathrm{Mo}, \mathrm{W}, \mathrm{Pd}$, and Ni were identified in the EDX spectrum of the $\mathrm{Pd}_{8} \mathrm{Ni}_{2} / \mathrm{rGO}-\mathrm{POM}$ sample (Fig. 2e). The obtained outcomes specified that the $\mathrm{Pd}_{8} \mathrm{Ni}_{2} / \mathrm{rGO}$ material is actually decorated by POM because just this POM structure contains Mo and W components. Moreover, the actual metal ( $\mathrm{Ni}$ and $\mathrm{Pd}$ ) loadings of the nanocatalysts have been determined using ICP-OES analysis to be around $10 \mathrm{wt} \%$.

TEM images for $\mathrm{Pd} / \mathrm{rGO}, \mathrm{Pd}_{8} \mathrm{Ni}_{2} / \mathrm{rGO}$, and $\mathrm{Pd}_{8} \mathrm{Ni}_{2} / \mathrm{rGO}-\mathrm{POM}$ samples are presented in Fig. 3. Noticeably, there are several spherically shaped nanoparticles over the surface of substrates, evidencing the effective preparation of metallic nanoparticulated catalysts on rGO. Besides, it is noteworthy to mention that the shape of the $\mathrm{Pd}_{8} \mathrm{Ni}_{2} / \mathrm{rGO}$ nanomaterial has no marked difference after decorated using POM.

Fig. $3 \mathrm{a}-\mathrm{c}$ shows that the $\mathrm{Pd}$ and $\mathrm{Pd}_{8} \mathrm{Ni}_{2}$ nanoparticles are evenly distributed on the rGO substrate in the $\mathrm{Pd} / \mathrm{rGO}, \mathrm{Pd}_{8} \mathrm{Ni}_{2}$ / rGO, and $\mathrm{Pd}_{8} \mathrm{Ni}_{2} / \mathrm{rGO}$-POM materials. As observed from XRD results, the deposition of $\mathrm{Pd}$ and $\mathrm{Pd}-\mathrm{Ni}$ on the rGO supports can lead to the generation of uniformly dispersed metal nanoparticles with smaller particle sizes compared to other previously reported catalysts on different substrates. ${ }^{58-60}$ These observations unambiguously imply that the rGO substrate is more suitable for anchoring well-dispersed Pd nanoparticles. The sizes of Pd-Ni nanoparticles are similar for both alloyed catalysts (Table 1), indicating that nanoparticle size influences on the catalytic abilities over the POM decorated $\mathrm{Pd}_{8} \mathrm{Ni}_{2} / \mathrm{rGO}$ electro-catalyst can be ignored in the current research. The results of TEM and XRD analyses reveal that the POMs decorated over the surface of $\mathrm{Pd}_{8} \mathrm{Ni}_{2} / \mathrm{rGO}$ nanocatalyst hardly affect its structural characteristics with the least remarkable aggregation of the $\mathrm{Pd}-\mathrm{Ni}$ nanoparticles.

\subsection{Electro-chemical properties of electro-catalysts}

3.2.1. Cyclic voltammetry (CV) and linear sweep voltammetry (LSV). To evaluate the electro-chemical behaviors of the synthesized $\mathrm{Pd} / \mathrm{rGO}, \mathrm{Pd}_{8} \mathrm{Ni}_{2} / \mathrm{rGO}$, and $\mathrm{Pd}_{8} \mathrm{Ni}_{2} / \mathrm{rGO}-\mathrm{POM}$ nanocatalysts for ORR, the $\mathrm{CV}$ measurements were performed in $\mathrm{O}_{2}$ saturated $0.1 \mathrm{M} \mathrm{KOH}$ electrolytes at a scan rate of $50 \mathrm{mV} \mathrm{s}^{-1}$ (Fig. 4). As indicated in Fig. 4, the peak potentials of ORR are noticed for each of the nanocatalysts. In comparison with the other two catalysts, $\mathrm{Pd}_{8} \mathrm{Ni}_{2} / \mathrm{rGO}$-POM exhibited more positive peak potential and greater current density towards oxygen reduction. This reveals a significant improvement in the oxygen reduction activities for $\mathrm{Pd}_{8} \mathrm{Ni}_{2} / \mathrm{rGO}$-POM relative to the $\mathrm{Pd}_{8} \mathrm{Ni}_{2} /$ rGO and Pd/rGO electro-catalysts. The improved ORR performance of the $\mathrm{Pd}_{8} \mathrm{Ni}_{2} /$ rGO-POM catalyst can be connected with beneficial synergistic effects of the alloyed Pd-Ni nanoparticles and rGO as well as the promotion of charge transfer between bimetallic nanoparticles and POM-modified surface of rGO substrate.

The LSV technique was applied to assess the intrinsic electret-catalytical activities of $\mathrm{Pd} / \mathrm{rGO}, \mathrm{Pd}_{8} \mathrm{Ni}_{2} / \mathrm{rGO}$, and $\mathrm{Pd}_{8} \mathrm{Ni}_{2} /$ rGO-POM nanomaterials for ORR in $\mathrm{O}_{2}$-saturated $0.1 \mathrm{M} \mathrm{KOH}$ electrolytes at a rotating speed of $1600 \mathrm{rpm}$ (Fig. 5a). $\mathrm{Pd}_{8} \mathrm{Ni}_{2} /$ rGO-POM demonstrated higher cathodic current density compared to other evaluated nanocatalysts. Noticeably, $\mathrm{Pd}_{8} \mathrm{Ni}_{2} /$ rGO-POM revealed a low ORR onset potential ( $\left.E_{\text {onset }}\right)$ at $-131 \mathrm{mV}$ vs. $\mathrm{Ag} / \mathrm{AgCl}$, which is more positive relative to that of the $\mathrm{Pd}_{8} \mathrm{Ni}_{2} / \mathrm{rGO}$ catalysts $(-152 \mathrm{mV})$, as well as that of the $\mathrm{Pd} /$ rGO catalyst $(-178 \mathrm{mV}$ ) (Table 2$)$, and comparable to that observed for Pt/C catalyst. ${ }^{61}$ The $\mathrm{Pd}_{8} \mathrm{Ni}_{2} / \mathrm{rGO}$-POM displays the highest mass activity (MA) among all nanocatalysts (presented in Table 2). For instance, the MA values of $\mathrm{Pd}_{8} \mathrm{Ni}_{2} / \mathrm{rGO}-\mathrm{POM}$ at

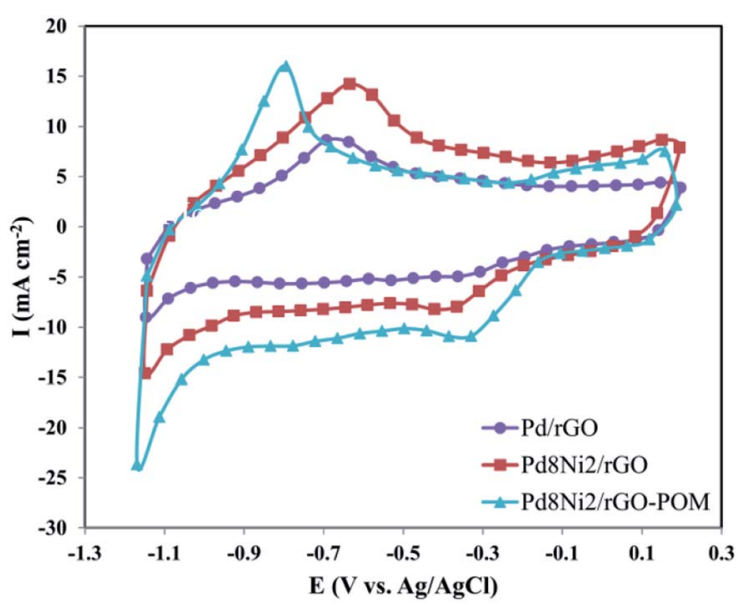

Fig. 4 The CV curves of the $\mathrm{Pd} / \mathrm{rGO}, \mathrm{Pd}_{8} \mathrm{Ni}_{2} / \mathrm{rGO}$, and $\mathrm{Pd}_{8} \mathrm{Ni}_{2} / \mathrm{rGO}-$ POM electro-catalysts in $\mathrm{O}_{2}$-saturated $0.1 \mathrm{M} \mathrm{KOH}$ solution at a scan rate of $50 \mathrm{mV} \mathrm{s}^{-1}$. 

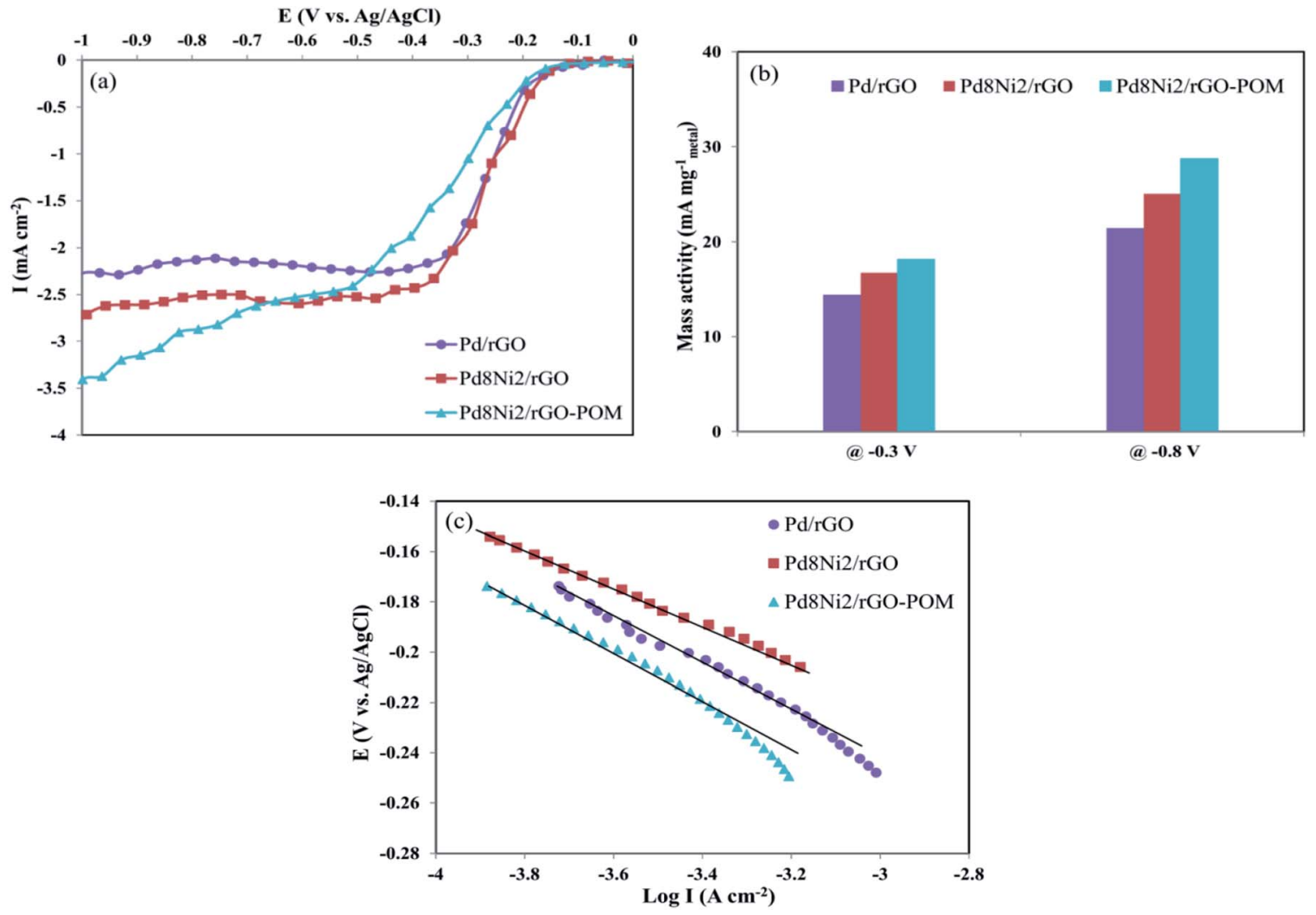

Fig. 5 The LSV curves of the $\mathrm{Pd} / \mathrm{rGO}, \mathrm{Pd}_{8} \mathrm{Ni}_{2} / \mathrm{rGO}$, and $\mathrm{Pd}_{8} \mathrm{Ni}_{2} / \mathrm{rGO}-\mathrm{POM}$ electro-catalysts in $\mathrm{O}_{2}$-saturated $0.1 \mathrm{M} \mathrm{KOH}$ solution at a scan rate of $5 \mathrm{mV} \mathrm{s}^{-1}$ and a rotating speed of $1600 \mathrm{rpm}$ (a). Comparative mass activity of these electro-catalysts at $-0.3 \mathrm{~V}$ and $-0.8 \mathrm{~V}$ (b). Tafel plots of all electro-catalysts (c).

Table 2 Electro-chemical properties of the $\mathrm{Pd} / \mathrm{rGO}, \mathrm{Pd}_{8} \mathrm{Ni}_{2} / \mathrm{rGO}$, and $\mathrm{Pd}_{8} \mathrm{Ni}_{2} / \mathrm{rGO}-\mathrm{POM}$ electro-catalysts in $0.1 \mathrm{M} \mathrm{KOH}$

\begin{tabular}{llll}
\hline Electro-catalyst & $\begin{array}{l}E_{\text {onset }} \\
(\mathrm{mV} v s . \mathrm{Ag} / \mathrm{AgCl})\end{array}$ & $\begin{array}{l}\text { MA at }-0.3 \mathrm{~V} \\
\left(\mathrm{~mA} \mathrm{mg} \mathrm{metal}^{-1}\right)\end{array}$ & $\begin{array}{l}\text { Tafel slope } \\
\left(\mathrm{mV} \mathrm{dec}^{-1}\right)\end{array}$ \\
\hline $\mathrm{Pd} / \mathrm{rGO}$ & -178 & 14.36 & 63.6 \\
$\mathrm{Pd}_{8} \mathrm{Ni}_{2} / \mathrm{rGO}$ & -152 & 16.74 & 61.5 \\
$\mathrm{Pd}_{8} \mathrm{Ni}_{2} / \mathrm{rGO}-\mathrm{POM}$ & -131 & 18.16 & 59.7
\end{tabular}

kinetic region $(-0.3 \mathrm{~V})$ and diffusion-limited region $(-0.8 \mathrm{~V})$ are 18.16 and $28.75 \mathrm{~mA} \mathrm{mg}_{\text {metal }}{ }^{-1}$, respectively, which are greater compared to those of the other investigated samples (Fig. $5 \mathrm{~b}$ ). These outcomes evidently unveil the boosted influence on oxygen reduction efficiencies using $\mathrm{POM}$ decorated on $\mathrm{Pd}_{8} \mathrm{Ni}_{2} /$ rGO catalyst.

Tafel analysis is very valuable in evaluating the electrochemical kinetics of the oxygen reduction process. Fig. 5c depicts the Tafel plots of prepared materials in the low current intensity region. In general, lower Tafel slope values are the indication of better catalytic performance towards ORR. Among the studied nanocatalysts, $\mathrm{Pd}_{8} \mathrm{Ni}_{2} / \mathrm{rGO}-\mathrm{POM}$ has the lowest Tafel slope of $59.8 \mathrm{mV} \mathrm{dec}^{-1}$ at the low current intensity area $(E /$ $\mathrm{V} \geq \sim-0.25 \mathrm{~V}$ ), as shown in Fig. $5 \mathrm{c}$ and Table 2. When the Pd-Ni alloyed nanocatalyst is decorated with the POMs, the Tafel slope value can be diminished, suggesting that the existence of POM is beneficial to the improvement of ORR kinetics. Remarkably, the value of the Tafel slope for $\mathrm{Pd}_{8} \mathrm{Ni}_{2} / \mathrm{rGO}$-POM showed excellent agreement with the typical values achieved for carbonsupported Pt catalyst in the literature. ${ }^{62,63}$ The close Tafel slope values of $\mathrm{Pd}_{8} \mathrm{Ni}_{2} / \mathrm{rGO}-\mathrm{POM}$ and $\mathrm{Pt} / \mathrm{C}$ manifest that the oxygen reduction kinetics is nearly similar for the two nanocatalysts.

Furthermore, LSVs were measured on the RDE for Pd/rGO and $\mathrm{Pd}_{8} \mathrm{Ni}_{2} / \mathrm{rGO}-\mathrm{POM}$ with $400-2000 \mathrm{rpm}$ at $5 \mathrm{mV} \mathrm{s}^{-1}$ scan rate (Fig. 6a and b). Fig. 6a and b show the RDE voltammograms of $\mathrm{Pd} / \mathrm{rGO}$ and $\mathrm{Pd}_{8} \mathrm{Ni}_{2} / \mathrm{rGO}-\mathrm{POM}$ with the achieved oxygen reduction currents. The increment in the currents was observed with the increment in the rotating rate, recommending the greater diffusion of oxygen to the surface of nanocatalyst directing to improved oxygen reduction via maximal transferred electron numbers. The cathodic current densities for $\mathrm{Pd}_{8} \mathrm{Ni}_{2} /$ rGO-POM were higher than those for Pd/rGO under identical rotating rates.

The obtained findings highlight the importance of the POM adsorption on the rGO surfaces with well-distributed Pd-Ni alloyed nanoparticles. On the base of RDE experiments, the number of the electrons transferred during the oxygen reduction procedure was estimated by the Koutecky-Levich $(\mathrm{K}-\mathrm{L})$ equation as defined below: ${ }^{64}$ 

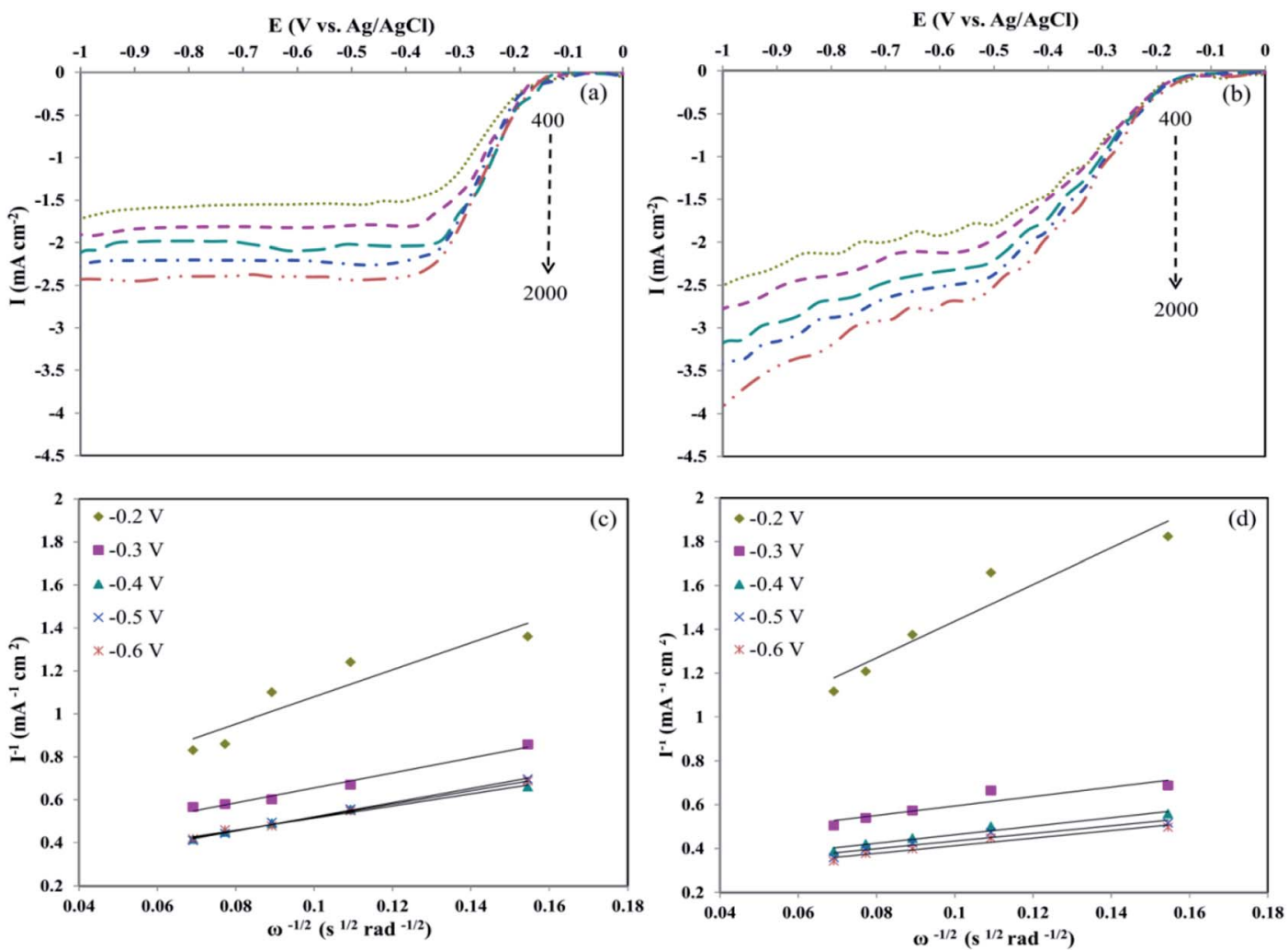

Fig. 6 The RDE voltammograms of the $\mathrm{Pd} / \mathrm{rGO}$ (a) and $\mathrm{Pd}_{8} \mathrm{Ni}_{2} / \mathrm{rGO}-\mathrm{POM}$ (b) in $\mathrm{O}_{2}$-saturated $0.1 \mathrm{M} \mathrm{KOH}$ solution with a scan rate of $5 \mathrm{mV} \mathrm{s}^{-1}$ at various rotating speeds (rpm). The corresponding Koutecky-Levich plots of the Pd/rGO (c) and $\mathrm{Pd}_{8} \mathrm{Ni}_{2} / \mathrm{rGO}-\mathrm{POM}$ (d) derived from RDE at different potentials.
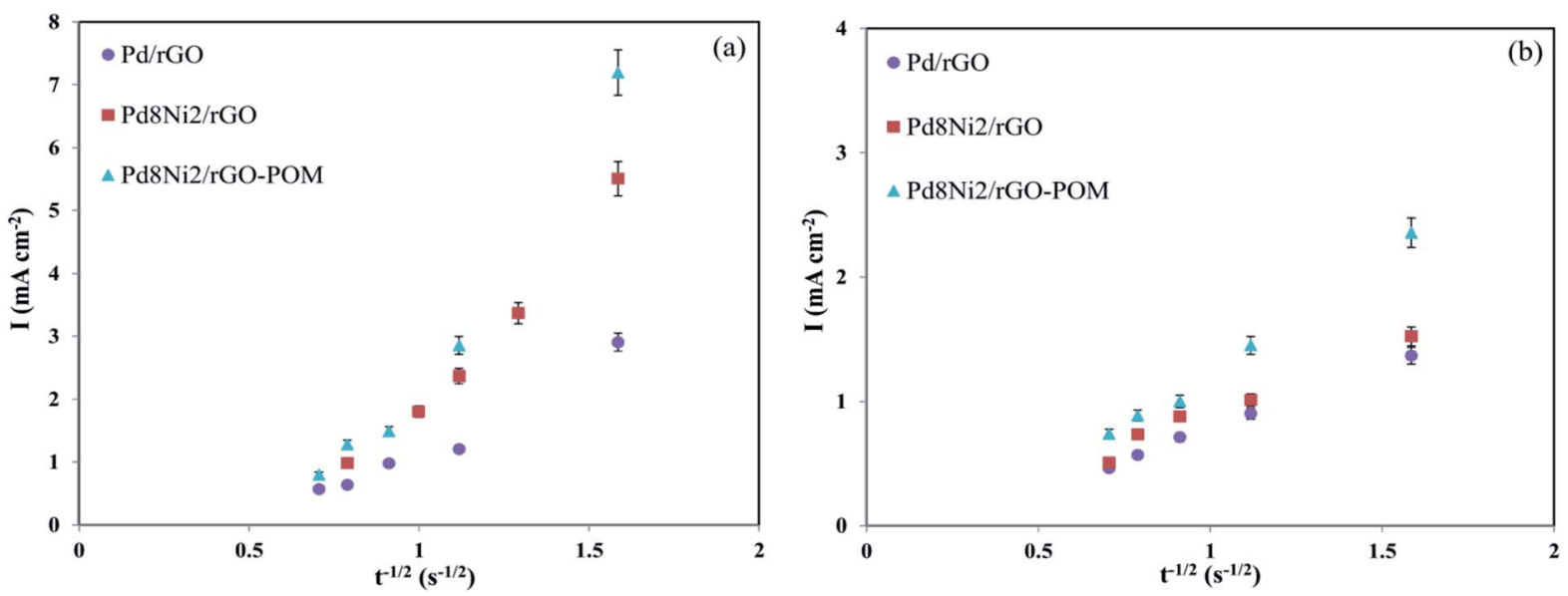

Fig. 7 Plots of / vs. $t^{-1 / 2}$ for the $\mathrm{Pd} / \mathrm{rGO}, \mathrm{Pd}_{8} \mathrm{Ni}_{2} / \mathrm{rGO}$, and $\mathrm{Pd}_{8} \mathrm{Ni}_{2} / \mathrm{rGO}-\mathrm{POM}$ electro-catalysts in $\mathrm{O}_{2}$-saturated $0.1 \mathrm{M} \mathrm{KOH}(\mathrm{a})$ and $0.1 \mathrm{M} \mathrm{KOH}$ containing $1 \mathrm{M}$ methanol (b).

$$
\begin{aligned}
& \frac{1}{I}=\frac{1}{I_{D}}+\frac{1}{I_{K}}=\frac{1}{B \omega^{1 / 2}}+\frac{1}{I_{K}} \\
& \omega=0.62 n F\left(D_{0}\right)^{2 / 3} C_{0} v^{-1 / 6}
\end{aligned}
$$

where $I$ is the acquired current density, $I_{\mathrm{K}}$ and $I_{\mathrm{D}}$ are the kinetic and diffusion-limited current density, respectively; $\omega$ is the electrode rotation rate $\left(\operatorname{rad~} \mathrm{s}^{-1}\right), n$ is the number of electrons transferred in the oxygen reduction, $F$ is the Faraday's constant (96485 $\mathrm{C} \mathrm{mol}^{-1}$ ), $D_{0}$ represents the diffusion coefficient of dissolved $\mathrm{O}_{2}\left(1.9 \times 10^{-5} \mathrm{~cm}^{2} \mathrm{~s}^{-1}\right), C_{0}$ expresses the concentration of dissolved $\mathrm{O}_{2}$ in the electrolyte $\left(1.2 \times 10^{-3} \mathrm{M}\right)$, and $u$ is the kinematic viscosity of the solution $\left(1 \times 10^{-2} \mathrm{~cm}^{2} \mathrm{~s}^{-1}\right){ }^{13,65,66}$

Fig. $6 \mathrm{c}$ and d illustrate the particular $\mathrm{K}-\mathrm{L}$ plots of $\mathrm{Pd} / \mathrm{rGO}$ and $\mathrm{Pd}_{8} \mathrm{Ni}_{2} /$ rGO-POM at selected electrode potentials drafted from 
Table 3 Oxygen permeabilities of the $\mathrm{Pd} / \mathrm{rGO}, \mathrm{Pd}_{8} \mathrm{Ni}_{2} / \mathrm{rGO}$, and $\mathrm{Pd}_{8} \mathrm{Ni}_{2} / \mathrm{rGO}$-POM electro-catalysts in the absence and presence of $1 \mathrm{M}$ methanol

\begin{tabular}{lll}
\hline & $\begin{array}{l}\text { In the absence } \\
\text { of methanol } D_{\mathrm{b}}{ }^{1 / 2} c_{\mathrm{b}} \\
\left(\mathrm{mol} \mathrm{cm}{ }^{-2} \mathrm{~s}^{-1 / 2}\right)\end{array}$ & $\begin{array}{l}\text { In the presence of } 1 \mathrm{M} \\
\text { methanol } D_{\mathrm{b}}{ }^{1 / 2} c_{\mathrm{b}} \\
\left(\mathrm{mol} \mathrm{cm}^{-2} \mathrm{~s}^{-1 / 2}\right)\end{array}$ \\
\hline $\mathrm{Pd} / \mathrm{rGO}$ & $1.33 \times 10^{-8}$ & $5.41 \times 10^{-9}$ \\
$\mathrm{Pd}_{8} \mathrm{Ni} / \mathrm{rGO}$ & $2.71 \times 10^{-8}$ & $6.59 \times 10^{-9}$ \\
$\mathrm{Pd}_{8} \mathrm{Ni}_{2} / \mathrm{rGO}-\mathrm{POM}$ & $3.79 \times 10^{-8}$ & $8.72 \times 10^{-9}$
\end{tabular}

the LSV curves. It evidently presented that the plots between $I^{-1}$ vs. $\omega^{-1 / 2}$ at diverse potentials for $\mathrm{Pd}_{8} \mathrm{Ni}_{2} / \mathrm{rGO}$-POM are more linear compared to those for $\mathrm{Pd} / \mathrm{rGO}$, which signified that the reduction of oxygen on the surface of the $\mathrm{Pd}_{8} \mathrm{Ni}_{2} / \mathrm{rGO}-\mathrm{POM}$ sample follows the first-order reaction kinetics. ${ }^{67,68}$ Based on eqn (1) and (2), the transferred electron numbers $(n)$ on the studied catalysts can be assessed by using the measured slope of those K-L plots. In calculated potential ranges, the average of $n$ values attained for catalyzing oxygen reduction on the $\operatorname{Pd}_{8} \mathrm{Ni}_{2}$ / rGO-POM is around 3.9, which is near those on the carbonsupported Pt electro-catalyst reported in the literature..$^{\mathbf{1 1 , 6 9 , 7 0}}$ This experimental result discloses that the nearly $4 \mathrm{e}^{-}$electron transfer mechanism is the predominant route for ORR catalysis on the $\mathrm{Pd}_{8} \mathrm{Ni}_{2} /$ rGO-POM catalyst in alkaline solution.

3.2.2. Chronoamperometry (CA). The chronoamperometric tests were utilized to examine the permeability of oxygen at the surface of fabricated electro-catalysts. The corresponding Cottrell plots ( $I$ vs. $t^{-1 / 2}$ ) of prepared nanocatalysts in $0.1 \mathrm{M} \mathrm{KOH}$ solutions are revealed in Fig. 7a. The oxygen permeability values $\left(D_{\mathrm{b}}{ }^{1 / 2} c_{\mathrm{b}}\right)$ attained from the slope of those $I v s . t^{-1 / 2}$ plots based on the modified Cottrell equation ${ }^{71}$ are reported in Table 3. As evidently seen in Fig. $7 \mathrm{a}$ and Table 3 , the $\mathrm{Pd}_{8} \mathrm{Ni}_{2} /$ rGO-POM possesses a greater oxygen permeability value comparing to other evaluated samples, and this observation verifies its boosted ORR electro-catalytic capability. It is inferred that the easier diffusion of oxygen on the $\mathrm{Pd}_{8} \mathrm{Ni}_{2} / \mathrm{rGO}-\mathrm{POM}$ surface can be assigned to the effect of alloying $\mathrm{Ni}$ with $\mathrm{Pd}$, unique porous structures of rGO substrate, along with POM modification of alloyed catalyst.

The chronoamperometric analyses of synthesized nanomaterials were also conducted to determine their oxygen permeability in $0.1 \mathrm{M} \mathrm{KOH}$ solutions containing $1 \mathrm{M}$ methanol (Fig. 7b). The oxygen permeabilities for the resultant nanocatalysts are presented in Table 3. It is noticeably observed that the modification of the rGO-supported $\mathrm{Pd}_{8} \mathrm{Ni}_{2}$ catalyst with POM can give rise to larger values of oxygen permeability relative to those of other studied samples in alkaline media saturated with methanol. For the prepared nanocatalysts, it is evident that with the existence of $1 \mathrm{M}$ methanol in the electrolyte, the permeabilities of oxygen are inferior to those without the addition of methanol. The inferior oxygen permeabilities of electro-catalysts in methanol-containing environments as compared with alkaline environments could be due to the accumulation of reactive positions for ORR by adsorbed methanol intermediates in the former environments. Remarkably, the chronoamperometric findings are consistent with the previously obtained experimental results in this study.

3.2.3. Methanol resistance and durability tests. The plausible crossover influence and long-term durability of nanocatalysts are considered as pivotal aspects for practicable implementation in the fuel cell systems. ${ }^{72,73}$ The methanol fuels at the anodic reservoir consistently pass across the membrane to the cathodic catalyst, which may lead to blocking the electrode potential equilibrium, thus diminishing the catalytic performance in fuel cells. The resistance to methanol crossover of $\mathrm{Pt} / \mathrm{C}$ and $\mathrm{Pd}_{8} \mathrm{Ni}_{2} / \mathrm{rGO}-\mathrm{POM}$ was assessed using the chronoamperometric response at $-0.4 \mathrm{~V} v s$. $\mathrm{Ag} / \mathrm{AgCl}$ in $\mathrm{O}_{2}$-saturated $0.1 \mathrm{M} \mathrm{KOH}$ solutions (Fig. 8a). As indicated in Fig. 8a, when methanol $(3 \mathrm{M})$ at $600 \mathrm{~s}$ was injected into the $0.1 \mathrm{M} \mathrm{KOH}$ solution, the oxygen reduction performance for $\mathrm{Pt} / \mathrm{C}$ electrocatalyst presents a dramatic decrease in current density,
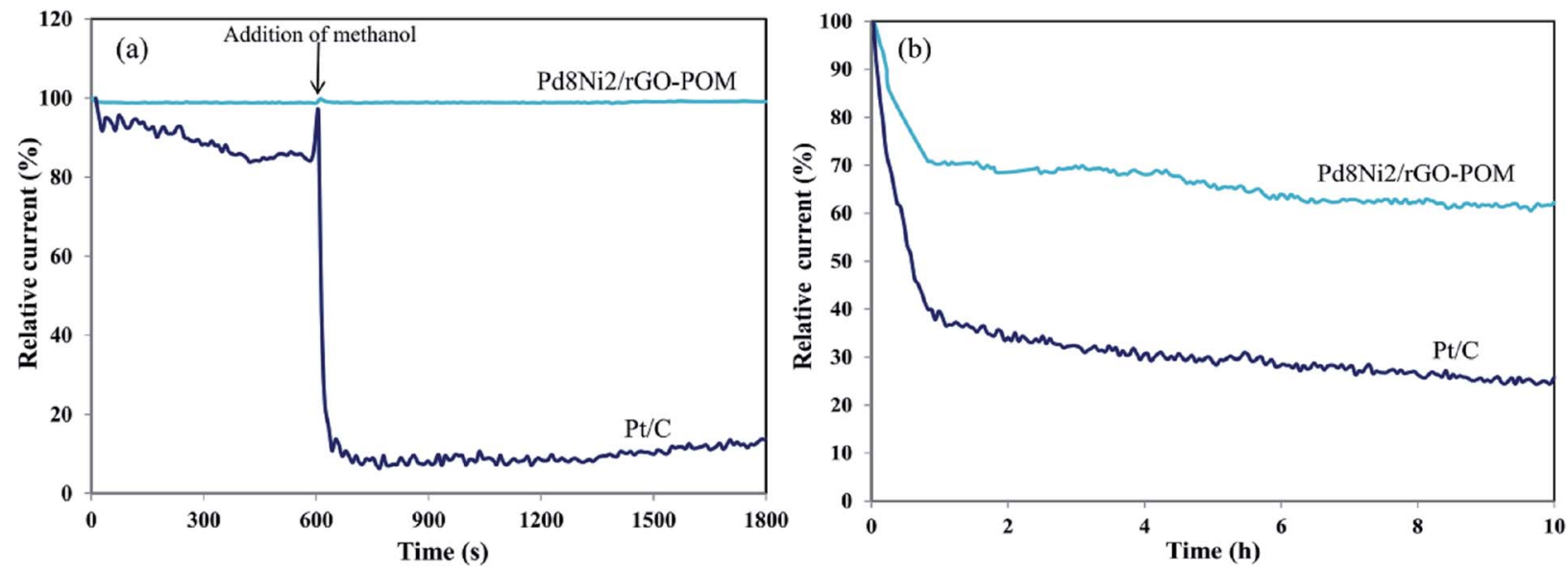

Fig. 8 Methanol resistance tests of the $\mathrm{Pd}_{8} \mathrm{Ni}_{2} / \mathrm{rGO}-\mathrm{POM}$ and commercial Pt/C upon adding $3 \mathrm{M}$ methanol after $600 \mathrm{~s}$ in $\mathrm{O}_{2}$-saturated $0.1 \mathrm{M}$ $\mathrm{KOH}$ solution at $-0.4 \mathrm{~V}$ vs. $\mathrm{Ag} / \mathrm{AgCl}(\mathrm{a})$. Current-time $(i-t)$ durability measurements of the $\mathrm{Pd}_{8} \mathrm{Ni}_{2} / \mathrm{rGO}-\mathrm{POM}$ and commercial $\mathrm{Pt} / \mathrm{C}$ in $\mathrm{O}_{2}-$ saturated $0.1 \mathrm{M} \mathrm{KOH}$ solution at $-0.4 \mathrm{~V}$ vs. $\mathrm{Ag} / \mathrm{AgCl}$ for $10 \mathrm{~h}$ (b). 
proposing the existence of the methanol oxidation. Conversely, $\mathrm{Pd}_{8} \mathrm{Ni}_{2} / \mathrm{rGO}-\mathrm{POM}$ recovers rapidly after the methanol injection. Therefore, the excellent resistance to methanol crossover and desired selectivity towards the reduction of oxygen make the prepared $\mathrm{Pd}_{8} \mathrm{Ni}_{2} / \mathrm{rGO}$-POM nanocatalyst an encouraging candidate for the cathodic electrodes in DMFCs.

Moreover, the long-term durability of the $\mathrm{Pd}_{8} \mathrm{Ni}_{2} / \mathrm{rGO}-\mathrm{POM}$ nanocatalyst towards oxygen reduction was tested using the chronoamperometry experiments in $\mathrm{O}_{2}$-saturated $0.1 \mathrm{M} \mathrm{KOH}$ at $-0.4 \mathrm{~V}$ vs. $\mathrm{Ag} / \mathrm{AgCl}$, as displayed in Fig. 8b. During the chronoamperometry analysis, $\mathrm{Pd}_{8} \mathrm{Ni}_{2} / \mathrm{rGO}-\mathrm{POM}$ exhibited greater durability, with almost $62.3 \%$ electro-catalytic ability retention after $10 \mathrm{~h}$ in alkaline condition, compared to that for carbonsupported Pt catalyst (just 25.8\% retention). The improved durability can be associated with well-distributed Pd-Ni nanoparticles on the rGO substrate and POM modification of the $\mathrm{Pd}_{8} \mathrm{Ni}_{2} / \mathrm{rGO}$ sample. This experimental outcome specifies that the fabricated $\mathrm{Pd}_{8} \mathrm{Ni}_{2} / \mathrm{rGO}$-POM nanocatalyst possesses superior durability for long-term usage as cathodic materials in alkaline fuel cell technologies.

On the basis of the above observations, the excellent ORR catalytic capability and methanol resistance of $\mathrm{Pd}_{8} \mathrm{Ni}_{2} / \mathrm{rGO}-$ POM could stem from several aspects. First, rGO, as a supporting material, improves electronic conductivity and mass transport capability. As well, the incorporation of $\mathrm{Ni}$ to Pd further enhances the catalytic activity and durability owing to the compressive strain and electronic ligand effects. When $\mathrm{Ni}$ is introduced into the Pd structure to make Pd-Ni alloy catalysts, the lattice of Pd is contracted, giving rise to the downshifted dband positions and the decreased oxygen-binding strength for Pd. The electronic constructions of Pd can also be amended by the electron coupling between $\mathrm{Pd}$ and $\mathrm{Ni}$ to reach enhanced oxygen reduction performance. Second, the porous nanostructures and modifications in the electronic features, originating from the interplay between $\mathrm{rGO}$ and POM, offer much more points to evenly disperse nanosized $\mathrm{Pd}-\mathrm{Ni}$ particles, available pathways for the permeation of oxygen during the ORR process and at the same time hamper the adsorption of methanol on reactive positions. Third, a synergistic effect of Pd$\mathrm{Ni}$, POM, and rGO is a benefit to promote the catalytic performances of fabricated catalysts..$^{27,40,46}$ Thereby, the $\mathrm{Pd}_{8} \mathrm{Ni}_{2} / \mathrm{rGO}-$ POM nanomaterial is anticipated to be employed as a novel candidate to develop efficient oxygen reduction nanocatalysts for DMFCs.

\section{Conclusions}

In this work, a novel Pd-Ni/rGO-POM electro-catalyst was efficiently fabricated using the impregnation technique towards the ORR. The physical and morphological characteristics of prepared samples were studied by XRD, FT-IR, Raman, ICPOES, FESEM-EDX, and TEM analyses. The outcomes verified the successful formation of nanocatalysts. The electro-chemical properties of fabricated nanocatalysts towards ORR were examined using $\mathrm{CV}, \mathrm{RDE}$, and CA. The $\mathrm{Pd}_{8} \mathrm{Ni}_{2} / \mathrm{rGO}-\mathrm{POM}$ demonstrated outstanding oxygen reduction ability under alkaline conditions, which could be attributed to the incorporation of Ni metallic elements with Pd, the deposition of $\mathrm{Pd}_{8} \mathrm{Ni}_{2}$ alloyed particles on the rGO support, as well as the decoration of $\mathrm{Pd}_{8} \mathrm{Ni}_{2} / \mathrm{rGO}$ alloy nanocatalyst with POM. The $\mathrm{Pd}_{8} \mathrm{Ni}_{2} / \mathrm{rGO}$-POM sample indicated impressive ORR electrocatalytic activity with a smaller Tafel slope, higher oxygen permeability, and a dominant 4-electron oxygen reduction process. In comparison with the commercially available $\mathrm{Pt} / \mathrm{C}$ catalyst, the resistance to the crossover of methanol and longterm durability were also considerably enhanced. $\mathrm{The} \mathrm{Pd}_{8} \mathrm{Ni}_{2} /$ rGO-POM material reported here exhibits the promising prospect to be a favorable cathode electro-catalyst for DMFCs.

\section{Author contributions}

Fereshteh Dehghani Sanij: conceptualization, investigation, methodology, formal analysis, writing - original draft. Prabhuraj Balakrishnan: investigation, writing - review \& editing. Huaneng Su: methodology. Lindiwe Khotseng: methodology, writing - review \& editing. Qian Xu: funding acquisition, supervision, writing - review \& editing.

\section{Conflicts of interest}

There are no conflicts to declare.

\section{Acknowledgements}

The work was fully supported by Grants from the NSFC, China (No. 51676092), State Key Laboratory of Engines at Tianjin University (No. K2020-14), Six-Talent-Peaks Project in Jiangsu Province (2016-XNY-015), High-Tech Research Key Laboratory of Zhenjiang City (No. SS2018002), and a Project Funded by the Priority Academic Program Development of Jiangsu Higher Education Institutions (PAPD), China.

\section{References}

1 S. K. Kamarudin, F. Achmad and W. R. W. Daud, Int. J. Hydrogen Energy, 2009, 34, 6902-6916.

2 J. Lv, N. Wisitruangsakul, J. Feng, J. Luo, K. Fang and A. Wang, Electrochim. Acta, 2015, 160, 100-107.

3 J. N. Tiwari, R. N. Tiwari, G. Singh and K. S. Kim, Nano Energy, 2013, 2, 553-578.

4 C. Shi and X. Maimaitiyiming, J. Alloys Compd., 2021, 867, 158732.

5 Z. Xiao, H. Wu, H. Zhong, A. Abdelhafiz and J. Zeng, Nanoscale, 2021, 13, 13896-13904.

6 X. Xu, Z. Xia, X. Zhang, H. Li, S. Wang and G. Sun, Nanoscale, 2020, 12, 3418-3423.

7 F. D. Sanij, P. Balakrishnan, P. Leung, A. Shah, H. Su and Q. Xu, Int. J. Hydrogen Energy, 2021, 46, 14596-14627.

8 L. M. Rivera-Gavidia, M. Luis-Sunga, J. L. Rodríguez, E. Pastor and G. García, Int. J. Hydrogen Energy, 2020, 45, 20673-20678.

9 B. Choi, W. H. Nam, D. Y. Chung, I. S. Park, S. J. Yoo, J. C. Song and Y. E. Sung, Electrochim. Acta, 2015, 164, 235242. 
10 Y. H. Xue, L. Zhang, W. J. Zhou and S. H. Chan, Int. J. Hydrogen Energy, 2014, 39, 8449-8456.

11 S. Yasmin, S. Cho and S. Jeon, Appl. Surf. Sci., 2018, 434, 905912.

12 M. Pandia Rajathi and S. Berchmans, Sci. Rep., 2019, 9, 1-13.

13 C. Goswami, H. Saikia, B. Jyoti Borah, M. Jyoti Kalita, K. Tada, S. Tanaka and P. Bharali, J. Colloid Interface Sci., 2021, 587, 446-456.

14 Y. Suo, L. Zhuang and J. Lu, Angew. Chem., 2007, 119, 29202922.

15 M. H. Shao, K. Sasaki and R. R. Adzic, J. Am. Chem. Soc., 2006, 128, 3526-3527.

16 K. Park, H. Matsune, M. Kishida and S. Takenaka, Int. J. Hydrogen Energy, 2017, 42, 18951-18958.

17 C. Lo Vecchio, D. Sebastián, C. Alegre, A. S. Aricò and V. Baglio, J. Electroanal. Chem., 2018, 808, 464-473.

18 S. Zhang, W. Wang, Y. Gao, S. Deng, L. Ding, H. Zhuo, Z. Bao, W. Ji, C. Qiu and J. Wang, Appl. Surf. Sci., 2021, 567, 150680.

19 W. Yan, Z. Tang, L. Wang, Q. Wang, H. Yang and S. Chen, Int. J. Hydrogen Energy, 2017, 42, 218-227.

20 J. Zhao, A. Sarkar and A. Manthiram, Electrochim. Acta, 2010, 55, 1756-1765.

21 F. Dehghani Sanij and H. Gharibi, Colloids Surf., A, 2018, 538, 429-442.

22 Z. Li, J. Li, K. Jiang, S. Yuan, D. Yu, H. Wei, Z. Shi, X. Li and H. Chu, Chem. Eng. J., 2021, 411, 128527.

23 K. Jukk, N. Alexeyeva, A. Sarapuu, P. Ritslaid, J. Kozlova, V. Sammelselg and K. Tammeveski, Int. J. Hydrogen Energy, 2013, 38, 3614-3620.

24 A. K. Geim and K. S. Novoselov, Nat. Mater., 2007, 6, 183-191.

25 P. Balakrishnan, F. Dehghani Sanij, P. Leung, H. Su, Q. Xu and T. S. Zhao, Chem. Eng. J., 2021, 417, 129280.

26 M. Martins, B. Šljukić, Ö. Metin, M. Sevim, C. A. C. Sequeira, T. Şener and D. M. F. Santos, J. Alloys Compd., 2017, 718, 204-214.

27 J. J. Lv, S. S. Li, A. J. Wang, L. P. Mei, J. R. Chen and J. J. Feng, Electrochim. Acta, 2014, 136, 521-528.

28 X. Wei, J. Wei, L. Huang, T. Yan and F. Luo, Inorg. Chem. Commun., 2017, 81, 10-14.

29 Y. Zhang, J. Liu, S. L. Li, Z. M. Su and Y. Q. Lan, EnergyChem, 2019, 1, 100021.

30 Y. Ji, L. Huang, J. Hu, C. Streb and Y. F. Song, Energy Environ. Sci., 2015, 8, 776-789.

31 A. Bijelic, M. Aureliano and A. Rompel, Angew. Chem., Int. Ed., 2019, 58, 2980-2999.

32 B. Hasenknopf, Front. Biosci., 2005, 10, 275-287.

33 Y. Wang and I. A. Weinstock, Chem. Soc. Rev., 2012, 41, 74797496.

34 M. Kourasi, R. G. A. Wills, A. A. Shah and F. C. Walsh, Electrochim. Acta, 2014, 127, 454-466.

35 S. Omwoma, W. Chen, R. Tsunashima and Y. F. Song, Coord. Chem. Rev., 2014, 258-259, 58-71.

36 G. Rousseau, S. Zhang, O. Oms, A. Dolbecq, J. Marrot, R. Liu, X. Shang, G. Zhang, B. Keita and P. Mialane, Chem.-Eur. J., 2015, 21, 12153-12160.
37 M. Nunes, D. M. Fernandes, I. M. Rocha, M. F. R. Pereira, I. M. Mbomekalle, P. de Oliveira and C. Freire, ChemistrySelect, 2016, 1, 6257-6266.

38 X. Xie, Y. Nie, S. Chen, W. Ding, X. Qi, L. Li and Z. Wei, J. Mater. Chem. A, 2015, 3, 13962-13969.

39 J. Sen Li, H. Q. Dong, S. L. Li, R. H. Li, Z. H. Dai, J. C. Bao and Y. Q. Lan, New J. Chem., 2016, 40, 914-918.

40 R. Liu, Z. Xian, S. Zhang, C. Chen, Z. Yang, H. Li, W. Zheng, G. Zhang and H. Cao, RSC Adv., 2015, 5, 74447-74456.

41 W. S. Hummers and R. E. Offeman, J. Am. Chem. Soc., 1958, 80, 1339.

42 R. Carrera-cerritos, V. Baglio, A. S. Aricò, J. Ledesma-garcía and M. F. Sgroi, Appl. Catal., B, 2014, 144, 554-560.

43 H. Wu, M. Zhou, Y. Qu, H. Li and H. Yin, Chin. J. Chem. Eng., 2009, 17, 200-206.

44 D. De, M. Chakraborty, S. Majumdar and S. Giri, Phys. Chem. Chem. Phys., 2014, 16, 19661-19667.

45 M. S. Ahmed and S. Jeon, ACS Catal., 2014, 4, 1830-1837.

46 H. Liu, C. Koenigsmann, R. R. Adzic and S. S. Wong, ACS Catal., 2014, 4, 2544-2555.

47 S. Wang, H. Li, S. Li, F. Liu, D. Wu, X. Feng and L. Wu, Chem.-Eur. J., 2013, 19, 10895-10902.

48 X. Zhang, X. Wang, L. Le, A. Ma and S. Lin, J. Electrochem. Soc., 2016, 163, F71-F78.

49 A. Ghosh, P. Chandran and S. Ramaprabhu, Appl. Energy, 2017, 208, 37-48.

50 S. Y. Shen, T. S. Zhao, J. B. Xu and Y. S. Li, J. Power Sources, 2010, 195, 1001-1006.

51 K. R. Lee and S. I. Woo, Catal. Today, 2014, 232, 171-174.

52 H. N. Tien, V. H. Luan, T. K. Lee, B. S. Kong, J. S. Chung, E. J. Kim and S. H. Hur, Chem. Eng. J., 2012, 211-212, 97-103.

53 B. Yuan, C. Bao, L. Song, N. Hong, K. M. Liew and Y. Hu, Chem. Eng. J., 2014, 237, 411-420.

54 P. Raghavendra, G. Vishwakshan Reddy, R. Sivasubramanian, P. Sri Chandana and L. Subramanyam Sarma, Int. J. Hydrogen Energy, 2018, 43, 4125-4135.

55 K. Gopalsamy, J. Balamurugan, T. D. Thanh, N. H. Kim, D. Hui and J. H. Lee, Composites, Part B, 2017, 114, 319-327.

56 S. S. Li, J. J. Lv, Y. Y. Hu, J. N. Zheng, J. R. Chen, A. J. Wang and J. J. Feng, J. Power Sources, 2014, 247, 213-218.

57 A. T. E. Vilian, S. K. Hwang, C. H. Kwak, S. Y. Oh, C. Y. Kim, G. W. Lee, J. B. Lee, Y. S. Huh and Y. K. Han, Synth. Met., 2016, 219, 52-59.

58 G. Ramos-Sánchez, M. M. Bruno, Y. R. J. Thomas, H. R. Corti and O. Solorza-Feria, Int. J. Hydrogen Energy, 2012, 37, 31-40.

59 Y. Soni, S. Gupta and C. P. Vinod, Mol. Catal., 2021, 511, 111732.

60 S. Limpattayanate and M. Hunsom, Renewable Energy, 2014, 63, 205-211.

61 N. Roy, S. Yasmin, A. Ejaz, H. Soon Han and S. Jeon, Appl. Surf. Sci., 2020, 533, 147500.

62 D. Roy, S. Sarkar, K. Bhattacharjee, K. Panigrahi, B. K. Das, K. Sardar, S. Sarkar and K. K. Chattopadhyay, Carbon, 2020, 166, 361-373.

63 S. Sarkar, S. Patel and S. Sampath, J. Power Sources, 2020, 445, 227280. 
64 K. K. Hazarika, Y. Yamada, E. V. Matus, M. Kerzhentsev and P. Bharali, J. Power Sources, 2021, 490, 229511.

65 J. Zhang, T. Zhang, J. Ma, Z. Wang, J. Liu and X. Gong, Carbon, 2021, 172, 556-568.

66 M. Sun, H. Liu, Y. Liu, J. Qu and J. Li, Nanoscale, 2015, 7, 1250-1269.

67 H. Chai, J. Xu, J. Han, Y. Su, Z. Sun, D. Jia and W. Zhou, J. Colloid Interface Sci., 2017, 488, 251-257.

68 Y. Wu, L. Ge, A. Veksha and G. Lisak, Nanoscale, 2020, 12, 13028-13033.
69 J. E. Choe, M. S. Ahmed and S. Jeon, J. Power Sources, 2015, 281, 211-218.

70 X. Xu, X. Yan, Z. Zhong, L. Kang and J. Yao, Carbon, 2019, 145, 311-320.

71 L. Zhang, C. Ma and S. Mukerjee, J. Electroanal. Chem., 2004, 568, 273-291.

72 X. Qin, Y. Huang, K. Wang, T. Xu, Y. Wang, P. Liu, Y. Kang and Y. Zhang, Electrochim. Acta, 2019, 297, 805-813.

73 L. Chai, Q. Huang, H. Cheng, X. Wang, L. Zhang, T. T. Li, Y. Hu, J. Qian and S. Huang, Nanoscale, 2020, 12, 8785-8792. 